\title{
A Primer on Ethics Education for Stem Cell and Biomedical Scientists
}

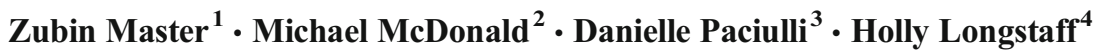

Published online: 11 October 2016

(C) Springer International Publishing AG 2016

\begin{abstract}
Stem cell research is an exciting field with clinical potential and has been rapidly moving towards the goal of translating research into therapeutics. Like all scientific fields, there are many ethical, legal, and social issues (ELSI) associated with stem cell research and stem cell scientists, especially trainees, should be aware of them. In this paper, we describe how course directors at academic institutions can develop training on ELSI of stem cell research for scientists. We describe how to perform a needs assessment and planning to develop pedagogical tools. We cover elements of course design, content and venue, and course evaluation. Lastly, we broadly discuss course topics including the responsible conduct of research, ethics of research involving animals and
\end{abstract}

This article is part of the Topical Collection on Ethics in Stem/Progenitor Cell Therapeutics

Zubin Master

zubin@zubsplace.com

Michael McDonald

mcdonald@ethics.ubc.ca

Danielle Paciulli

Danielle.Paciulli@alumni.stonybrook.edu

Holly Longstaff

holly.engageassociates@gmail.com

1 Alden March Bioethics Institute, Albany Medical College, 47 New Scotland Avenue, MC 153, Albany, NY 12208-3478, USA

2 W. Maurice Young Centre for Applied Ethics, University of British Columbia, 227-6356 Agricultural Road, Vancouver, BC V6T 1Z2, Canada

3 Center for Medical Humanities, Compassionate Care, and Bioethics, Stony Brook University, Health Sciences Center, Level 3-080, Stony Brook, NY 11794-8335, USA

4 Engage Associates Consulting Group, Vancouver, BC, Canada humans, and stem cell ethics and policy. This paper is meant to be a practical guide for course directors interested in developing ELSI pedagogy for stem cell scientists.

Keywords Stem cell education - Ethical, legal social issues (ELSI) $\cdot$ Ethics of research involving humans $\cdot$ Ethics of research involving animals $\cdot$ Responsible conduct of research . Research integrity

\section{Introduction}

The rapid growth of stem cell research (SCR) makes it an exciting field not only for its clinical potential but also because of the rich ethical, legal/policy and social issues (ELSI). Ethics has become widely accepted as a core component of good science [1,2] and medical education [3] with some calling for mandatory education in research ethics for all graduate students [4]. Given this, stem cell scientists should be informed of the ethical legal and social dimensions of SCR and have a solid footing on research and applied ethics.

In this paper, we outline an ethics curriculum for stem cell scientists being mindful that much of the subject topics discussed form a core basis of ethics education for all biomedical scientists. We draw on the academic and gray literature and our collective experiences in helping formulate our perspective with the practical goal to help faculty further reflect on how to design an ELSI curriculum for stem cell scientists. The aim of ethics education for stem cell researchers is to understand the ELSI of SCR, develop a sense of moral responsibility of research, understand the ethical conduct of scientific research, and develop ethical reasoning skills. Our approach to developing an ethics training program containing three important elements is as follows: (1) needs assessment, (2) robust course design, and (3) course evaluation. Based on a 
translational ethics approach [5], we outline four broad topic areas appropriate for science trainees (typically graduate students and fellows) engaged in SCR: responsible conduct of research (RCR), the ethics of research involving animals (RIA), the ethics of research involving humans (RIH), and stem cell ethics and policy.

\section{ELSI Course Development for SCR Scientists}

Development of a single course or program requires a systematic method [6••]. Here, we provide a three-step process to help design ELSI courses for SCR scientists: needs assessment and planning; course design, content, and venue; and course assessment.

\section{Needs Assessment and Planning}

Training on research integrity and human and animal subjects is mandated nationally through policies in many countries [7-11]. Regardless of the need or interest in developing an educational program, a needs assessment and program planning are the important first steps. This phase involves research and data collection using social science methods to help instructors understand the needs and receive buy-in from different stakeholders, understand institutional culture, work within budget, and design an effective course/program and tools to evaluate effectiveness [6••, 12-14]. In the absence of this effort, ethics education might be created to address issues important to its creators or one party instead of the needs of scientists. While some or even many scientists may report that ethics education is unnecessary, it should be made clear from the beginning of the needs assessment that the goal here is to determine the direction of the ethics curriculum, not its necessity. Finding the resources, time, and expertise to carry out meaningful ethics education is challenging $[15,16]$ and a needs assessment and planning helps course directors understand the lay of the land and ensures focus and efficiency in course/program design. The needs assessment can be done in two components: performing content analysis of documents and capturing the views of stakeholders using interviews and surveys.

A needs assessment can begin by performing a literature and web search on (1) potential topics to cover in the course, e.g., the responsible conduct of research, ethics of research involving animals and humans, and stem cell ethics; (2) relevant international, national, state/provincial, and institutional policies; and (3) courses offered at other institutions. Providing a literature/document assessment serves to help inform course directors about topics, identify existing resources, recruit participants for the needs assessment, and identify experts as potential instructors. Document analysis involves qualitative content analysis where coders analyze the literature and course outlines to develop a comprehensive list of topics and skills. While it is beyond the scope of this paper to describe content analysis and other methodologies discussed, we refer readers to several excellent sources [17-19].

A second set of analyses for the needs assessment involves capturing stakeholder perceptions including scientists (graduate students, fellows, and faculty); institutional faculty and staff including members of animal and human research ethics committees, research integrity officers or equivalent (i.e., VP Research); research compliance officers; research ethics instructors; and possibly governmental or policy experts external to the institution. The goal of capturing stakeholder perceptions is to assess the knowledge and knowledge gaps, skills and attitudes towards ethics training, and institutional culture. Considering there is extensive variation in the views of instructors on RCR topics and their expertise [20], capturing instructors' perception is important to determine expertise and gain perspectives on the value of different topics and student feedback. Several social science methods including individual interviews, focus groups, and surveys can be used to capture stakeholder perceptions [18, 21-28]. Document analysis discussed earlier should help in developing questions for interviews and surveys.

Two authors of this paper undertook a needs assessment to develop an online, nationwide ethics course for stem cell scientists based on a grant awarded by Canada's Stem Cell Network [29]. The aim was to understand the topics and their importance to the Canadian SCR community. The needs assessment employed 17 semi-structured interviews and focus groups with 26 participants involving stem cell science trainees, principal investigators, research ethics board members, and governance experts across Canada. Results of these discussions were analyzed and coded for common themes [30] and used to create an online survey to determine the representativeness of findings. The combined qualitative and quantitative results were translated into an interactive website and thematic content where researchers could navigate using portholes that addressed the ethics of different stages of translational SCR. The content of the website was developed by topic experts (some of whom participated in the needs assessment) and was updated regularly until the end of its funding in 2016. While active, the viewership grew steadily reaching 3615 visitors internationally [29]. A needs assessment can also be done timely and without external funding by faculty: short recorded interviews with extensive note taking can avoid transcription saving in time and money, and surveys can be easily implemented for larger groups.

\section{Course Design, Content, and Venue}

All courses, including ethics courses, must be well-designed, delivered effectively to engage students, and the content reviewed prior to teaching the course. This means course 
objectives must be clearly stated, realistic, and should direct the teaching tool to be used. Additionally, courses need to be evaluated by capturing student perceptions and assessing skills using validated measures. In this subsection, we discuss several facets regarding the design of SCR ethics courses.

Course Objectives Course objectives should be clearly stated and instructional methods must stem from objectives meaning a one-size fits all method, i.e., case studies, is unlikely to address all objectives [31]. Traditionally, ethics was taught in medical schools using lectures [32]; many today use cases because they are known to stimulate active learning and student engagement [33-36]. Yet a range of instructional tools can be used to promote discussion and critical thinking including written and online case studies, interactive videos, in-class writing assignments, role playing exercises, group debates, team-based learning, journal clubs, and performing in-class surveys [32, 37-41]. The method to engage students (i.e., case studies) should not be conflated with the teaching goal (e.g., to engage students and heighten discussion) [20, 37]. When using case studies to teach stem cell scientists, cases are not required to be specific to stem cell research. Cases surrounding ethical issues in laboratory conduct or human subject research can be general and are found in most texts (see Table 1). Although not necessary, such cases can easily be modified in the context of stem cell science.

Course instructors need to have clear course aims and remain realistic about whether they can be achieved $[6 \bullet \bullet$. While there is agreement about the need to foster ethical awareness and a culture of ethics in the lab, there is little consensus about how these goals should be achieved. Ethics education efforts frequently have unclear goals and vary in quality and effectiveness [2]. How ethics education is incorporated into training programs and the resources available also lack consistency $[1,42]$. All research ethics courses not only aim to deliver knowledge about principles, practices, and policies but can also teach ethical problem solving skills, ethical sensitivity skills, and may alter behavior (attitudes and values) with the goal of increasing ethicality and motivating ethical action of scientists [31]. Scientists may be trained to better recognize ethical issues, raise questions, remain professional, and seek the appropriate resources and tools to address ethical situations. Assessing ethical sensitivity and problem solving skills, and ethicality are difficult metrics to measure and measurements are only beginning to be developed, validated, and tested [43-47].

Course Structure Antes (2014) outlines several elements of format and structure including an online, classroom or hybrid format, length of course, type of audience and depth of content, choosing instructors, the pace of learning activities, and whether the instructional format and structure align with the learning objectives.

Increasingly, applied ethics training is moving online which is more than simply placing materials on a website as effective online teaching focuses more on learning rather than outcomes [48]. Studies on the effectiveness of online versus classroom teaching show little difference based on the method of instruction [49-52]. However, there are several advantages and disadvantages to online learning.

Online learning permits students to be off-site offering greater flexibility. As ethics case discussions are important to transfer knowledge and gain skills in ethical decision-making, online discussions are asynchronous without the use of realtime chatting technology. Asynchronous discussions permit the exchange of ideas, provide students who are shy a forum where they can write responses, and allow students to contribute to the discussion on their own time [53, 54]. While online discussion boards encourage some students to speak, others hide behind the scenes contributing minimally [55]. Distance learning may provide richer discussions and permits a greater diversity of perspectives because students from around the world contribute and share experiences heightening student awareness and appreciation for cultural diversity. An ideal number of students to consider for ethics courses is $\sim 10-15$ students in order to elicit a rich discussion where all contributions can be heard. Some might fear that there is less social interaction in online teaching, but the interaction is different and can provide unique ways for students to connect. Online classes permit students to be independent learners and to have higher expectations for themselves by being self-starters, organized, flexible, and creative $[48,55,56]$. In addition, technical skills and problems can impede effective online learning for both teachers and students.

While course planning is performed continuously, some decisions on structure and format need to be made early in course/program development.

\section{Course Assessment and the Effectiveness of Research Ethics Training}

Most course directors place greater emphasis on developing content and less on evaluation. Assessing students may be ongoing (formative feedback) or after learning (summative feedback). Course evaluations should be performed throughout the course and instructors should develop or use existing reliable tools to assess outcomes being mindful of their personal assumptions and biases, and acknowledging the limits of assessment tools. Evaluation requires considerable expertise in terms of teaching and evaluation if the measures used to assess different elements of a course are valid. Depending on course objectives, assessment tools 
Table 1 Specific topics and resources for RCR, RIA, RIH, and stem cell ethics and policy

Responsible conduct of research

Topics: (1) science and social responsibility, (2) data acquisition, management, sharing, and ownership, (3) mentor/trainee responsibilities, (4) publication practices and responsible authorship, (5) peer review, (6) collaborative science, (7) research misconduct, (8) conflict of interest and commitment, (9) dual use research, (10) intellectual property, and (11) policies and procedures

Resources

1. Macrina FL. 2014. Scientific Integrity, 4th Ed. ASM press: Washington DC.

2. Shamoo AE, Resnik DB. 2015. Responsible Conduct of Research. Oxford University Press: NY.

3. Steneck NH. 2007. ORI. Introduction to the Responsible Conduct of Research. http://ori.hhs.gov/images/ddblock/rcrintro.pdf.

4. CITI Program: Collaborative Institutional Training Initiative. https://www.citiprogram.org/

5. U.S. Office of Research Integrity (ORI) http://ori.hhs.gov/ (see "RCR Resources," "Research Misconduct" and "Policies Regulations" tabs)

6. Steneck N, Anderson M, Kleinert S, Mayor T (Eds). 2015. Integrity in the Global Research Arena. World Scientific: Singapore.

7. Mayer T, Steneck N (Eds). 2012. Promoting Research Integrity in a Global Environment. World Scientific: Singapore.

8. National Academy of Sciences, National Academy of Engineering, Institute of Medicine. 1997. Adviser, Teacher, Role Model, Friend: On being a mentor to students in science and engineering. National Academy Press: Washington DC.

9. Godlee F, Jefferson T (Eds). (2003). Peer Review in the Health Sciences 2nd Ed. BMJ Books: London.

10. International Committee of Medical Journal Editors (ICMJE). Recommendations for the Conduct, Reporting, Editing, and Publication of Scholarly Work in Medical Journals. http://www.icmje.org/recommendations/.

11. Committee on Publication Ethics (COPE) (see Resources tab for codes of conduct, flowcharts, guidelines and other resources. http://publicationethics.org/.

Research involving animals

Topics: (1) moral status and animal rights, (2) animal welfare, and (3) policies and procedures

Resources

1. Donaldson S, Kymlicka W. 2011. Zoopolis: A political theory of animal rights. Oxford: Oxford University Press.

2. Regan T. 1983. The case for animal rights. University of California Press: Berkeley

3. Singer P. 1995. Animal Liberation. Random House: New York

4. Bentham J. 1970. An Introduction to the Principles of Morals and Legislation. Burns JH, Hart HLA (Eds). Oxford University Press: London.

5. Fraser D. 2013. Understanding Animal Welfare: the science in its cultural context. Wiley: Hoboken.

6. Singer P (Ed). 2006. In Defense of Animals. The Second Wave. Blackwell Publishing: Singapore.

7. Macrina FL. 2014. Scientific Integrity, 4th Ed. ASM press: Washington DC.

8. Shamoo AE, Resnik DB. 2015. Responsible Conduct of Research. Oxford University Press: NY.

9. Steneck NH. 2007. ORI. Introduction to the Responsible Conduct of Research.

10. CITI Program: Collaborative Institutional Training Initiative. https://www.citiprogram.org/

11. United States Department of Agriculture (USDA) National Agricultural Library. Animal Welfare Act and Regulations.

https://www.nal.usda.gov/awic/animal-welfare-act.

Research involving humans

Topics: (1) historical cases of tragedies in RIHs, e.g., Nuremberg Trials, Jewish Chronic Disease Hospital, Tuskegee Syphilis Study, Henry Beecher Study, and others; (2) overview of norms, principles, and practices of RIHs; (3) overview of regulatory system, and institutional review and multisite review; (4) ethics of clinical trials research, clinical equipoise, placebos in research; informed consent; (5) payments and participation; (6) fair subject selection and access to research; (7) risks and benefits in research; and (8) research with specific populations, e.g., mental disorders, children, prisoners, students, minority groups

Resources

1. Emanuel EJ, Grady C, Crouch RA, Lie RK, Miller FG, Wendler D (Eds). 2008. The Oxford Textbook of Clinical Research Ethics. Oxford University Press: NY.

2. Research Ethics: Text and Readings by Deborah R. Barnbaum and Michael Byron, Prentice Hall, 2001

3. Integrity in Scientific Research: Creating an Environment That Promotes Responsible Conduct Institute of Medicine, National Research Council, National Academy Press, 2002

4. CITI Program: Collaborative Institutional Training Initiative. https://www.citiprogram.org/

5. Macrina FL. 2014. Scientific Integrity, 4th Ed. ASM press: Washington DC.

6. Shamoo AE, Resnik DB. 2015. Responsible Conduct of Research. Oxford University Press: NY.

7. Steneck NH. 2007. ORI. Introduction to the Responsible Conduct of Research. http://ori.hhs.gov/images/ddblock/rcrintro.pdf.

8. Rothman DJ. 1991. Strangers at the Bedside: A History of How Law and Bioethics Transformed Medical Decision Making.

Basic Books: New York.

9. Skloot R. 2010. The Ommortal Life of Henrietta Lacks. Crown Publishers: New York.

10. Kimmelman J, London AJ. 2015. The structure of clinical translation: efficiency, information and ethics. Hastings Center Report 45:27-39.

11. Smith E, Master Z. 2014. Ethical practice of research involving humans. Reference Module in Biomedical Research. doi:10.1016/B978-0-12-801238-3.00178-1.

12. Emanuel EJ, Wendler D, Grady C. 2000. What makes clinical research ethical? JAMA 283:2701-2711.

13. U.S. Office of Human Research Protections (OHRP). https://www.hhs.gov/ohrp/. (See Regulations \& Policy and Education \& Outreach tabs).

14. Canadian Institutes of Health Research (CIHR). Ethics in Research: A Science Life Cycle Approach. http://www.cihr-irsc.gc.ca/e/48635.html. 
Table 1 (continued)

Stem cell ethics and policy

Topics: (1) moral status of human embryos and parthenotes, (2) harms to women, (3) ethics of research and reproductive cloning, (4) clinical translation and commercialization of SCR, (5) premature translation and the "stem cell tourism" industry, (6) hype in science and effective communication of science to patients and the public, (7) biobanking cells and tissues, and (8) policy and procedures

Resources

1. Master Z. 2014. Ethics of stem cell research: the unresolved issues. Reference Module in Biomedical Research. doi:10.1016/B978-0-12-801, 238-3.00021-0.

2. Knoepfler P. 2013. Stem Cells An Insider's Guide. World Scientific: Singapore.

3. Gruen L, Grabel L, Singer P. 2007. Stem Cell Research. The Ethical Issues. Blackwell Publishing: Oxford.

4. International Society for Stem Cell Research. A closer look at stem cells. http://www.closerlookatstemcells.org

5. International Society for Stem Cell Research. Guidelines for stem cell research and clinical translation. http://www.isscr.org/docs/default-source/guidelines/isscr-guidelines-for-stem-cell-research-and-clinical-translation.pdf?sfvrsn=2

6. NIH Guidelines on Human Stem Cell Research. 2009. http://stemcells.nih.gov/policy/pages/2009guidelines.aspx.

7. National Research Council, Institute of Medicine. 2010. Final Report of the National Academies' Human Embryonic Stem Cell Research Advisory Committee and 2010 Amendments of the National Academies' Guidelines for Human Embryonic Stem Cell Research.

8. Gottweis H, Petersen A (Eds). 2008. Biobanks. Governance in Comparative Perspective. Routledge: NY.

9. Elger B, Biller-Andorno N, Mauron A, Capron AM. 2008. Ethical Issues in Governing Biobanks. Global Perspectives. Ashgate: Surrey, England

Many of the policy and procedure resources are based on US laws and regulations

can examine knowledge, ethical problem solving skills, ethical sensitivity skills, and attitudes and values [6••]. Course assessment can also include student satisfaction scores.

Typically, students anonymously complete satisfaction surveys at the end of the course, but student satisfaction is not fully indicative of gaining knowledge and acquiring skills [6••]. Measuring ethical problem solving and sensitivity skills requires the use of vignettes describing ethical situations and attitudes and may require evaluation of written reflective essays $[6 \bullet \bullet$. These latter instruments and evaluation techniques require effort to develop and must be validated to ensure that the measure is truly examining the element being assessed. The ethical decision-making measure, professional decisionmaking measure, ethical sensitivity tests, and "how I think about research" test are validated instruments to assess skills and attitudes in research ethics courses. While these instruments have only recently been developed, the effectiveness of research ethics training remains questionable.

The effectiveness of research ethics training has been met with some to no improvement and, in some cases, has been shown to have negative consequences [34, 35, 57-62, 63•, $64,65]$. Using pre/post-survey measurements, Powell et al. (2006) showed significant improvements in knowledge with modest impact on ethical decision-making and attitudes in a short-term RCR course. Antes et al. (2010) found that RCR training had no improvement on ethical behavior and decreased in behaviors to seek help or consider others' perspectives and increased deception, retaliation, and avoidance of personal responsibility. A recent meta-analysis examining the effectiveness of different RCR educational and policy interventions resulted in some short-term effects on knowledge and modest effects at influencing participants to avoid plagiarism, but conclusions were difficult to make due to low-quality evidence [63•]. These studies indicate that the effectiveness of research ethics training may be restricted to offering knowledge and possibly some improvement in recognizing and handling ethical problems. For this reason, Michael Kalichman recommends that the primary goal of RCR education be to "foster a research culture in which conversations about responsible conduct of research are expected and acceptable" [37]. Because assessing research ethics training for scientists is only in its infancy, making sweeping conclusions on its effectiveness is premature. These studies indicate that further research is needed and that educators need to set modest goals regarding research ethics education and design or adopt existing metrics to evaluate whether course goals are met. Course evaluation should be done in conjunction with course planning and development to ensure evaluation tools accurately measure course objectives.

\section{Course Content: Research Ethics and Stem Cell Ethics}

Stem cell scientists work in highly specialized areas with some strictly performing in vitro biochemical experiments while others work more with animals or humans. Accordingly, scientists have different backgrounds, skills, and interests. For there to be progress in translating SCR, it is vital that trainees have a sense not only of their particular roles and responsibilities in research but to also have an outlook towards other areas of SCR. Stem cell scientists should have a sense of the larger collective responsibilities to patients, research participants, sponsors, the public, and the social institutions in which they operate. For this reason, we adopt a translational model of ethics education for stem cell scientists where ethics content includes the responsible conduct of research (RCR), ethics of research involving animals (RIA), ethics of research involving humans (RIH), and stem cell ethics and policy [5]. RCR, RIA, $\mathrm{RIH}$, and stem cell ethics and policy can be taught as separate courses or elements included in a single course. 
There are three reasons for separating these topics: (1) All scientists need to conduct scientific research under ethical parameters and should know about the ethical conduct of scientific research. For example, the topic of conflicts of interest, defined as an external interest influencing the professional judgment of a researcher [66], can happen in a laboratory or clinical setting. (2) RCR, RIA, and RIH have different governance mechanisms $[9,67]$ and mandates to promote education $[9,68,69]$ which impacts efforts to teach and promote ethical behavior in each area. (3) The literature and resources on RCR, RIA, and RIH are generally separated in many colleges and universities. In addition, scientists are routinely required to take RCR, RIA, and RIH courses depending on compliance measures and national and institutional policies. The structure of courses and emphasis on different topics will depend on the establishment of courses within the institution and the needs of the trainees, faculty, and administration.

We adopt the view that ELSI courses for scientists should move beyond discussion of basic ethical theories or principles - such as the moral status of animals or embryos - to taking responsibility for one's decisions, reporting malfeasance, and having the courage to raise ethical issues in practice and address them collegially. This approach is especially important for stem cell scientists due to heightened scrutiny of SCR because of several high-profile cases of scientific misconduct. We want ethics not to be viewed as compliance measures for scientists, but rather have ethics embedded into the everyday practice of science. A central concern should be with the cultivation of an ethical culture in the research environment. Moving from an exclusively individual focus ("What should I do?") to an organization focus ("What should we do?) is critical in terms of developing ethical leadership skills. Scientists should be familiar with moral reasoning and be able to recognize the various actors in an ethical situation, understand individual and institutional interests and expectations, duties and obligations, and the consequences of actions [70, 71].

We argue that ethics education in RCR, RIA, and RIH needs to be focused on ethically substantive issues that pervade all of the areas rather than the bureaucratic processes and paperwork necessary for ethics approval [4, 37, 72]. A myopic view of ethics as a set of rules reduces ethics to compliance detracting from a healthy debate. It is equally important to teach scientists that the compliance and oversight measures are challenged and susceptible to change [73-75]. Ethical issues may not always be solvable and well-informed and motivated people will disagree on issues. Part of the training for scientists is to teach that moral uncertainty and disagreement is part of the challenge in the ethics of SCR.

While some believe in an integrated ELSI and stem cell science curriculum [76], we have chosen to separate ELSI training from biomedical science training, but are mindful that the two can be integrated. Our aim for this section is to provide some subject matter content (Table 1), but we encourage course directors to undertake their own evaluation to identify subtopics of interest in alignment with the needs of individuals at their institution.

\section{Teaching the Responsible Conduct of Research}

For the most part, research scientists are self-governing professionals who conduct research upholding the principles of research integrity [77]. RCR (a.k.a. research or scientific integrity) captures a range of principles and practices governing ethical research, including preventing research misconduct (fabrication, falsification, and plagiarism); data acquisition, management, sharing, and ownership; authorship and publication ethics; mentor and trainee responsibilities; ethics of animal and human research; peer review; and conflicts of interest (COIs) [78]. Given the publicity surrounding research misbehaviors in SCR, teaching the norms and practices surrounding RCR is important for stem cell scientists. In 2000, the US Office of Research Integrity outlined nine instructional areas of RCR courses: (1) data acquisition, management, sharing, and ownership, (2) mentor/trainee responsibilities, (3) publication practices and responsible authorship, (4) peer review, (5) collaborative science, (6) human subjects, (7) research involving animals, (8) research misconduct, and (9) conflict of interest and commitment [79]. Yet several studies have shown that RCR courses vary significantly in content and best practices [20, 42, 80, 81]. Based on a 2009 Delphi study, expert panelists recommended ORI's nine overarching objectives with the emphasis of two new core areas: the social responsibilities of scientists and current topics [67]. While the panel agreed on the addition of these new core areas, there remained no consensus on the topics. We recommend ELSI courses for stem cell scientists cover the nine overarching areas, but to treat RIA and RIH separately because there are rich resources for each topic and likely are established courses within institutions. The current topics recommended by Delphi panelists could include components we discuss in the stem cell ethics and policy topic. In addition, RCR training could incorporate the public communication of science and respective policies and procedures including how to address an allegation.

Practices governing RCR vary from country to country and adopt a variety of legal and policy instruments [9]. For example, US colleges and universities have research integrity officers that serve to facilitate inquiries and investigations of research misconduct within institutions; such individuals are less clearly identified in Canada where ethics boards, VP offices, and other administrative committees handle research misconduct. The US regulations define research misconduct as fabrication, falsification, and plagiarism, whereas Canada, among other nations, has adopted broader definitions of RCR capturing scientific dishonesty, misappropriation of 
authorship, or funding among other violations [9, 82]. Appropriate national and institutional policies governing RCR should be explained to trainees in addition to institutional procedures on addressing allegations. International recommendations, i.e., the International Committee of Medical Journal Editors' recommendations on authorship and publication ethics among others, should be provided. The principles, practices, and relevant policies for RCR are discussed further in Table 1.

\section{Teaching the Ethics of Research Involving Animals}

An initial starting point for RIAs is discussing why and how animals are used in research. Moving to clinical trials of SCR would not be allowed to proceed without promising research on animal models. It is thus essential to address the basis of ethical concerns around RIAs, i.e., what makes an organism morally deserving of our attention? In this area, there is a rich literature and debate around positions ranging from anthropocentric views - only humans deserve moral consideration - to conceptions that animals have inherent moral value [83]. Advocates for the moral status of animals include consequentialist Peter Singer who argues that because animals are sentient (have feelings), their utility in terms of pleasure and pain must be taken into account in RIAs [84] and Tom Regan who holds that animals like humans have a status that gives them rights [85].

On the other hand, there are those who hold that moral status belongs only to beings that can enter reciprocal relationships of moral responsibility with other moral agents. As nonhuman animals lack moral agency, they are not part of the moral community except insofar as they are valued by those who have moral agency meaning animals matter morally if they matter to other humans as property or food sources [86].

The question of what animals think, communicate, and suffer has not only been the subject of philosophical debate but also the object of empirical investigation in zoology, animal biology, and animal welfare. It is important for teachers and students to be aware that research in animal welfare yields new insights on the situation of RIAs. For example, most regulations around RIAs have centered on animal pain and numbers but more recent research has shown conditions enabling lab animals to flourish allowing the expression of species typical behaviors.

Students need then to understand the substance and context of debates around the use of RIAs for the primary purpose of improving human health and welfare. Moreover, it should not be assumed that all stem cell trainees are equally comfortable with animal research. Some will have misgivings. Students should learn about objections and counterarguments to the use of RIAs. However, the mainstream view among scientists and institutions is that sentient animals have varying levels of awareness and feelings, and thus, their interests ought to be taken into consideration in RIAs. The issue then is whether sufficient measures are taken to treat the animals involved in research in a humane way.

Here, two questions are central in determining whether RIAs are justified: (a) is the research at a stage where it is likely to be advanced by the use of animals (the "good science" question) and (b) are the animals used (and often sacrificed) in humane ways (the "good ethics" question). A critical issue for (a) is whether animal use provides a good model for reaching findings relevant to human health. In some cases, concerns about scientific validity and relevance of particular animal models to human health are raised [87]. Question (b) leads into a discussion of oversight of RIAs which in most countries is governed by institutional committees that review research protocols based on regulations, guidelines, and other policies. Committee members typically include scientists, ethicists, veterinarians, and members of the public who review and decide whether to approve RIA protocols. While there is considerable variance in international regulatory regimes for RIAs, guiding principles are set in terms of "the three Rs" enunciated by Russell and Burch:

1. Reduce the number of animals used, e.g., avoiding needless replication of studies

2. Refine the research to minimize the distress of animals

3. Replace animals where possible by the use of different models of research (e.g., in vitro testing or computer modeling) [88]

Once these more fundamental issues are on the table, the stage is set for discussing specific responsibilities of researchers and research institutions in regard to the use of RIAs. Here, as elsewhere, it is useful to discuss current and previous examples from stem cell and allied areas of research which include creating animal-human chimeras, hybrids, and germline transfer using adult and pluripotent stem cells.

\section{Teaching the Ethics of Research Involving Humans}

The ethics of RIHs has a developed set of mainstream values and norms. The four biomedical ethics principles - autonomy, non-maleficience, beneficence, and justice - serve as the foundation for specific norms and practices for RIHs. Emanuel et al. (2000) provide a checklist of norms specific to ethical RIHs: scientific/clinical value, scientific validity, fair subject selection, favorable risk-benefit ratio, informed consent, protecting privacy, withdrawal, and undertaking regulatory review [89•]. Crucial issues to be considered for SCR scientists include the following:

- What differentiates research from treatment?

- Clinical equipoise as a necessary condition for randomized clinical trials 
- The use of placebos in research

- Ethics at the four stages of randomized clinical trials

- Fair selection of participants

- Informed consent as a process of engagement and communication with participants throughout the research process

- Risks and benefits of research, including the psychosocial harms of research

- Communication of research results

- Working with different populations of research participants such as children, the cognitively impaired, captive populations, minority, and other communities (Table 1)

The norms and practices above are reflected in core documents in human research protection such as the Belmont Report, the Canadian Tri-Council Policy Statement, the Nuremberg Code, the Declaration of Helsinki and regulatory documents such as the US Common Rule. Due to the historical cases of abuse in RIHs, a formal governance model has become widespread in many nations, most of which operate as institutional review boards although centralized and other review models are becoming commonplace [90-92]. Reflection on central values in ethical RIHs can be further assisted by examining the aforementioned policies governing clinical research, including regulations by the US Food and Drug Administration or Health Canada. These can be used to encourage discussion of the responsibilities of researchers and research teams towards participants.

\section{Teaching Stem Cell Ethics and Policy}

The ethics of SCR is captured under the umbrella of the ethics of RIHs, but there remain many unique elements to SCR that deserve special attention in a separate course. Our approach to teaching stem cell ethics and policy is to focus on some of the principles and ethical issues surrounding SCR (Table 1). Earlier debates surrounding SCR focused on the moral status of human embryos and whether embryos can be created for research purposes while current issues surround patenting and commercialization, privacy protections of embryo donors, and unproven stem cell interventions (a.k.a. "stem cell tourism") [93]. An ELSI course on SCR can cover several of these topics, the public communication of SCR, and the policies and practices of SCR.

Ethical issues of SCR in the late 1990s to mid-2000 surrounded the creation of new lines from human embryonic stem cells (hESCs) and the potential use of somatic cell nuclear transfer (SCNT-a.k.a. cloning technology) [94•]. Considerable attention was given to determine whether human embryos had sufficient moral status (equivalent to persons) deserving of moral protection. Several personhood theories can be discussed including potentiality (embryos have the potential to be born, grow up, and have a valuable life and thus deserve protection), cognitive capacities (only sentient persons with advanced cognition deserve protection), and showing respect to embryos irrespective of moral status [95-97]. The strengths and weaknesses of these moral theories can be discussed to show the intractability of the debate surrounding the moral status of embryos. Beyond questions of moral status, earlier ethical debates surrounding SCR honed in on the potential physical and social harms to women as egg providers $[98,99]$. Harms to women debates were set in the context of cloning where advocates for the use of SCNT believed it necessary to obtain ova from women in order to bypass immune rejection of transplanted stem cells. The goal is to encourage discourse, heighten appreciation, and foster a reciprocal understanding of views even if they do not align with one's own morality.

It is equally important to cover practical topics to scientists including hype and effective communication, commercialization, and unproven stem cell interventions. Hype can be defined as positive or negative exaggerations of science [100]. Hype surrounding SCR has been about the promise of SCR to lead to cures in the near future [101]. Stem cell therapies have yet to be realized, and some believe the hype over SCR has contributed to the premature commercialization of unproven stem cell interventions, commonly termed stem cell tourism $[102,103]$. Providers offer to treat a range of diseases with stem cell interventions creating a global, direct-to-consumer market. While originally unproven stem cell interventions were thought to be offered in countries with lax regulatory standards [104], these interventions are beginning to be offered in highly regulated countries most notably the USA [105-107]. Educating scientists about the features of the stem cell tourism industry and strategies to mitigate SCR have been met with much excitement and enthusiasm by scientists [108-113].

Stem cell scientists should also learn the ethics of translation (covered in ethics of RIHs), but specific to SCR and include topics, i.e., informed consent for clinical SCR, clinical trial design related to transplantation of stem cells, risks surrounding the transplantation of pluripotent and adult stem cells, and issues impeding translation, i.e., immunogenicity and scaling up. The International Society for Stem Cell Research (ISSCR) has recently released Guidelines for Stem Cell Research and Clinical Translation which provides recommendation on the clinical translation and commercialization of SCR for the stem cell science community [114]. Stem cell researchers should learn what a translational and commercialization ethos in science means in terms of changes in funding policies [115-117], increase in university-driven patents and licenses [118, 119], and the potential pressure to translate and commercialize results $[120,121]$. The commercialization ethos has called into question a range of ethical and integrity issues including minimizing data sharing and increase in competition and secrecy [121-124], potential bias 
of research and ghost authorship [125, 126], and the potential to adversely impact public participation in research [127]. Topics surrounding hype, commercialization, stem cell tourism, and effective communication are intimately intertwined and represent some of the current tangible ethics issues that would be of direct interest and practical significance to stem cell scientists.

Along with understanding ethical issues surrounding translation and commercialization, SCR scientists should also be taught responsible public engagement and how to communicate science freely and accurately [117]. While public outreach activities offer publicity to scientists, some have made exaggerated claims about stem cell therapies. The ISSCR guidelines outline that SCR scientists "should promote accurate, balanced, and responsive public representations of stem cell research" [114]. Scientists should be made aware of the problems of hyping science and should take care in the accurate portrayal of the state of SCR. Additional institutional resources, i.e., media communication officers, should be made known to scientists. Due to patients accessing the internet about unproven stem cell interventions, patients may reach out to stem cell scientists for medical advice. Stem cell researchers should avoid providing medical advice to patients and instead encourage patients to seek medical advice from physicians, direct them to ClinicalTrials.gov, and offer various patient booklets and web resources on stem cell therapies [128 $-130]$.

Another topic of significance for stem cell researchers surrounds the use of human biological materials as a potential source of stem cells. Scientists should know that the public does have concerns about the storage and use of human biological materials especially when it relates to research or sharing that is not aligned with the views of individuals and can cause discrimination or stigmatization [100, 131-133]. Because scientists operate biobanks or are end users of biorepository material, ethical issues surrounding informed consent for biobanking and the ethical and social risks of biobanking should be taught. The concept that discarded tissue is no longer of interest to the donor is not universal. Several landmark legal cases in the USA, Canada, and elsewhere could be used to illustrate specific individual and community desire for control over consenting to use their samples and information [134-137]. Research involving tissues raises other questions such as privacy protection, future insurability, ethnic or racial stereotyping, and genetic discrimination [98]. In some cases, there are ethical standards of behavior around research uses of tissue, such as anonymization and delinking from identifying information. However, it may be that there is no way of completely preventing the reidentification of participants through the use of genetic information, biobanking, and public databases.

A final subtopic of importance surrounds the governance and ethical practice of SCR. In the USA, Canada, and elsewhere, there are specific governance mechanisms that oversee pluripotent SCR, especially in the derivation of new hESC lines and other techniques involving the creation or use of human embryos. For example, in the USA, Institutional Stem Cell Oversight Committees (ISCROs) or their derivatives oversee embryonic SCR within institutions among other techniques involving human and animal embryos.

A stem cell ethics and policy course should complement and develop topics beyond the RCR, RIA, and RIH courses specifically tailored to stem cell scientists. Stem cell researchers should have a fundamental background on ethical research conduct, including with animals and humans so as to understand how these issues pertain specifically to SCR. For example, understanding the parameters surrounding informed consent would help in discussing consent as it relates to biorepository research. Emphasis on the topics discussed in stem cell ethics and policy should be based on the needs and interests of scientists.

\section{Conclusion}

Teaching scientists research ethics and ELSI related to specific topics is becoming standard practice in biomedical and other scientific fields. There, however, remain significant differences in the extent of coverage of topics, how they are taught, and the effectiveness of teaching research ethics to scientists. We undertake a comprehensive review of the academic literature on teaching research ethics to scientists. Our practical goal is to provide a general protocol for course directors to develop an ELSI course for stem cell scientific researchers. We describe many of the shortcomings in ethics education for scientists and hope that by following the steps outlined here, including needs assessment and planning, that course directors are able to develop pedagogy efficiently and which serves the needs of scientists at their department and institution. We also cover four topics that should be included in ELSI education. While the topics outlined in RCR, RIA, and RIH are general for all bench and clinical scientists, we emphasize teaching ELSI of SCR so as to provide direct context for stem cell scientists. Ethics training should accompany scientific training so scientists advance research in an ethical way. ELSI training for stem cell researchers will also permit scientists to be better communicators to the public and advocates for the advancement of science.

Acknowledgments We would like to thank Paola Pinto Vidal for work on the manuscript, and the reviewers and Section Editor Dr. Brooke Ellison for helpful suggestions.

\section{Compliance with Ethical Standards}

Conflict of Interest The authors have no conflicts of interest in the publication of this article. 
Human and Animal Rights and Informed Consent This article does not contain any studies involving human or animal subjects.

\section{References}

Papers of particular interest, published recently, have been highlighted as:

- Of importance

•. Of major importance

1. Godbold R, Lees A. Ethics education for health professionals: a values based approach. Nurse Educ Pract. 2013;13:553-60.

2. Carrese JA, Malek J, Watson K, Lehmann LS, Green MJ, McCullough LB, et al. The essential role of medical ethics education in achieving professionalism: the Romanell report. Acad Med. 2015;90:744-52.

3. Giubilini A, Milnes S, Savulescu J. The medical ethics curriculum in medical schools: present and future. J Clin Ethics. 2016;27:129-45.

4. Mitcham C, Snieder R. Science for sale: improve ethics education. Science. 2014;343:137.

5. Joffe S, Miller FG. Bench to bedside: mapping the moral terrain of clinical research. Hastings Cen Rep. 2008;38:30-42.

$6 . \bullet$ Antes AL. A systematic approach to instruction in research ethics. Accountability in Research. 2014;21:50-67. This article outlines a systematic approach to developing research ethics training and discusses similar steps we have outlined in this review.

7. National Institutes of Health. Update on the requirement for instruction in the responsible conduct of research. NIH Guide for Grants and Contracts 2011.

8. National Science Foundation. Responsible conduct of research. Federal Register August 20 2009; 74(160):42126-8.

9. Resnik DB, Master Z. Policies and initiatives aimed at addressing research misconduct in high-income countries. PLoS Med. 2013;10:e1001406.

10. Tri-Agencies. The tri-agency framework: responsible conduct of research. 2011. http://www.rcr.ethics.gc.ca/eng/policypolitique/framework-cadre/. Accessed 19 August 2016.

11. Canadian Institutes of Health Research. Ethics office education workbook. 2014. http://www.cihr-irsc.gc.ca/e/48832.html. Accessed 19 August 2016.

12. Brown J. Training needs assessment: a must for developing an effective training program. Public Pers Manage. 2002;31:569-78.

13. Bosher S, Smalkoski K. From needs analysis to curriculum development: designing a course in health-care communication for immigrant students in the USA. Engl Specif Purp. 2002;21:59-79.

14. Gould D, Kelly D, White I, Chidgey J. Training needs analysis: a literature review and reappraisal. Int J Nurs Stud. 2004;41:471-86.

15. Byrne J, Straub H, DiGiovanni L, Chor J. Evaluation of ethics education in obstetrics and gynecology residency programs. Obstet Gynecol. 2015;212:397.e1-397.e8.

16. Manson HM, Satin D, Nelson V, Vadiveloo T. Search family medicine share links. Fam Med. 2013;46:28-35.

17. Forman J, Damschroder L. Qualitative content analysis. In: Jacoby L, Siminoff L, editors. Empirical research for bioethics: a primer. Oxford, UK: Elsevier Publishing; 2008. p. 39-62.

18. Bernard HR. Social research methods: qualitative and quantitative approaches. Thousand Oaks, CA: Sage; 2012.

19. Neuendorf KA. The content analysis guidebook. Thousand Oaks, CA: Sage Publications; 2002.
20. Kalichman MW, Plemmons DK. Reported goals for responsible conduct of research courses. Acad Med. 2007;82:846-52.

21. Creswell JW. Research design: qualitative, quantitative, and mixed methods approaches. Thousand Oaks, CA: Sage Publications; 2013.

22. Pearlman RA, Starks HE. Quantitative surveys. In: Sugarman J, Sulmasy DP, editors. Methods in medical ethics. Washington, DC: Georgetown University Press; 2010.

23. Alexander GC, Wynia MK. Survey research in bioethics. Bradford, UK: Emerald Group Publishing Limited; 2007. p. 139-60.

24. Fowler Jr FJ. How unclear terms affect survey data. Public Opin Q. 1992;56:218-31.

25. Ulrich CM, Ratcliffe SJ. Hypothetical vignettes in empirical bioethics research. Bradford, UK: Emerald Group Publishing Limited; 2007. p. 161-81.

26. Taylor B, Hull SC, Kass N. Qualitative methods. In: Sugarman J, Sulmasy DP, editors. Methods in medical ethics. 2nd ed. Washington, DC: Georgetown University Press; 2010. p. 193-214.

27. Simon CM, Mosavel M. Ethical design and conduct of focus groups in bioethics research. In: Jacoby L, Siminoff LA, editors. Empirical methods for bioethics: a primer. Oxford, UK: Elsevier Publishing; 2008. p. 63-81.

28. Sankar P, Jones NL. Semi-structured interviews in bioethics research. In: Jacoby L, Siminoff LA, editors. Empirical methods for bioethics: a primer. Oxford, UK: Elsevier Publishing; 2008. p. 117-36.

29. McDonald M, Longstaff H. Spinning a stem cell ethics web. Accountability in Research. 2013;20:107-26.

30. Longstaff $\mathrm{H}$, Schuppli CA, Preto N, Lafrenière D, McDonald M. Scientists' perspectives on the ethical issues of stem cell research. Stem Cell Rev Rep. 2009;5:89-95.

31. Antes A, DuBois JM. Aligning objectives and assessment in responsible conduct of research instruction. J Microbiol Biol Educ. 2014;15:108-16.

32. Fox E, Arnold RM, Brody B. Medical ethics education: past, present, and future. Acad Med. 1995;70:761-8.

33. Herreid CF. Cautionary tales: ethics and case studies in science. $\mathrm{J}$ Microbiol Biol Educ. 2014;15:208-12.

34. Antes AL, Murphy ST, Waples EP, Mumford MD, Brown RP, Connelly S, et al. A meta-analysis of ethics instruction effectiveness in the sciences. Ethics Behav. 2009;19:379-402.

35. Thiel CE, Connelly S, Harkrider L, Devenport LD, Bagdasarov Z, Johnson JF, et al. Case-based knowledge and ethics education: improving learning and transfer through emotionally rich cases. Sci Eng Ethics. 2013;19:265-86.

36. Harkrider L, MacDougall AE, Bagdasarov Z, Johnson JF, Thiel $\mathrm{CE}$, Mumford MD, et al. Structuring case-based ethics training: how comparing cases and structured prompts influence training effectiveness. Ethics Behav 2013(just-accepted).

37. Kalichman M. Rescuing responsible conduct of research (RCR) education. Accountability in Research. 2014;21:68-83.

38. Master, Z. Relevance of case-based studies in workshops on RCR for diverse audiences. Office of Research Integrity Newsletter 2014;22:6-8. http://ori.hhs.gov/images/ddblock/march_vol22 no2.pdf

39. Fragasso M, Capozzi V. Introducing ethics in your instruction using a TED talks playlist. J Microbiol Biol Educ. 2014;15:246.

40. Jones NL, Peiffer AM, Lambros A, Guthold M, Johnson AD, Tytell M, et al. Developing a problem-based learning (PBL) curriculum for professionalism and scientific integrity training for biomedical graduate students. J Med Ethics. 2010;36:614-9.

41. McCormack WT, Garvan CW. Team-based learning instruction for responsible conduct of research positively impacts ethical decision-making. Accountability in Research. 2014;21:34-49. 
42. DuBois JM, Schilling DA, Heitman E, Steneck NH, Kon AA. Instruction in the responsible conduct of research: an inventory of programs and materials within CTSAs. Clinical and Translational Science. 2010;3:109-11.

43. Antes AL, Chibnall JT, Baldwin KA, Tait RC, Vander Wal JS, DuBois JM. Making professional decisions in research: measurement and key predictors. Accountability in Research 2016(justaccepted).

44. Mumford MD, Connelly S, Brown RP, Murphy ST, Hill JH, Antes AL, et al. A sensemaking approach to ethics training for scientists: preliminary evidence of training effectiveness. Ethics Behav. 2008;18:315-39.

45. Borenstein J, Drake, M, Kirkman, R and Swann J. The test of ethical sensitivity in science and engineering (TESSE): a discipline-specific assessment tool for awareness of ethical issues. Annual ASEE Conference, American Society for Engineering Education, Pittsburgh, PA; 2008.

46. DuBois JM, Chibnall JT, Gibbs J. Compliance disengagement in research: development and validation of a new measure. Sci Eng Ethics. 2015:1-24.

47. Clarkeburn H. A test for ethical sensitivity in science. J Moral Educ. 2002;31:439-53.

48. Sieber JE. Misconceptions and realities about teaching online. Sci Eng Ethics. 2005;11:329-40.

49. Ni AY. Comparing the effectiveness of classroom and online learning: teaching research methods. Journal of Public Affairs Education. 2013;19:199-215.

50. Johnson SD, Aragon SR, Shaik N, Palma-Rivas N. Comparative analysis of learner satisfaction and learning outcomes in online and face-to-face learning environments. J Interact Learn Res. 2000;11:29.

51. Neuhauser C. Learning style and effectiveness of online and faceto-face instruction. The American Journal of Distance Education. 2010;16:99-113.

52. Swan K. Learning effectiveness online: what the research tells us. Elements of Quality Online Education, Practice and Direction. 2003;4:13-47.

53. Cummings $\mathrm{M}$. Web-based education in science and engineering ethics-topic and technology barriers. Sci Eng Ethics. 2005;11:386-8.

54. Muilenburg LY, Berge ZL. Student barriers to online learning: a factor analytic study. Distance Education. 2005;26:29-48.

55. Shrestha B. Challenges and opportunities in classroom dynamics in an online as opposed to an on-site class-a paradigm shift. J Phys Math. 2015;6:1-2.

56. Zhang D, Zhao JL, Zhou L, Nunamaker Jr JF. Can e-learning replace classroom learning? Commun ACM. 2004;47:75-9.

57. Kalichman MW, Friedman PJ. A pilot study of biomedical trainees' perceptions concerning research ethics. Acad Med. 1992;67:769-75.

58. Antes AL, Wang X, Mumford MD, Brown RP, Connelly S, Devenport LD. Evaluating the effects that existing instruction on responsible conduct of research has on ethical decision making. Acad Med. 2010;85:519-26.

59. Powell ST, Allison MA, Kalichman MW. Effectiveness of a responsible conduct of research course: a preliminary study. Sci Eng Ethics. 2007;13:249-64.

60. Titus SL. Evaluating US medical schools' efforts to educate faculty researchers on research integrity and research misconduct policies and procedures. Accountability in Research. 2014;21:9-25.

61. Anderson MS, Horn AS, Risbey KR, Ronning EA, De Vries R, Martinson $\mathrm{BC}$. What do mentoring and training in the responsible conduct of research have to do with scientists' misbehavior? Findings from a national survey of $\mathrm{NIH}$-funded scientists. Acad Med. 2007;82:853-60.
62. Eastwood S, Derish P, Leash E, Ordway S. Ethical issues in biomedical research: perceptions and practices of postdoctoral research fellows responding to a survey. Sci Eng Ethics. 1996;2:89-114.

63. Marusic A, Wager E, Utrobicic A, Sambunjak D, Anderson MS, Rothstein HR. Interventions to prevent misconduct and promote integrity in research and publication. The Cochrane Library 2016. This recent meta-analysis reviews and analyzes multiple policy and educational interventions developed and tested to promote research integrity and publication ethics.

64. Schmaling KB, Blume AW. Ethics instruction increases graduate students' responsible conduct of research knowledge but not moral reasoning. Accountability in Research. 2009;16:268-83.

65. Jordan SR, Gray PW. Responsible conduct of research training and trust between research postgraduate students and supervisors. Ethics Behav. 2012;22:297-314.

66. McDonald M, Preto C. Conflict of interest in health research. In: Chadwick R, ten Have H, Meslin E, editors. The sage book of health care ethics: core and emerging issues. Thousand Oaks: Sage Publications; 2011. p. 326-41.

67. Dubois JM, Dueker JM. Teaching and assessing the responsible conduct of research: a delphi consensus panel report. J Res Adm. 2009;40:49-70.

68. Master Z, McDonald M, Williams-Jones B. Promoting research on research integrity in Canada. Accountability in Research. 2012;19:47-52.

69. Resnik DB, Dinse GE. Do U.S. research institutions meet or exceed federal mandates for instruction in responsible conduct of research? A national survey. Acad Med. 2012;87:1237-42.

70. Bebeau MJ, Pimple KD, Muskavitch KM, Borden SL, Smith DH. Moral reasoning in scientific research: cases for teaching and assessment. Poynter Center for the Study of Ethics and Assessment. 1995;7:112-43.

71. Macrina FJ. Scientific integrity: text and cases in responsible conduct of research. 4th ed. Washington, DC: ASM Press; 2014.

72. McDonald $\mathrm{M}$. The governance of health research involving human subjects (HRIHS). Law Commission of Canada 2000.

73. Caulfield T, Kamenova K, Ogbogu U, Zarzeczny A, Baltz $\mathrm{J}$, Benjaminy S, et al. Research ethics and stem cells: is it time to re-think current approaches to oversight? EMBO Rep. $2015 ; 16: 2-6$.

74. Greely HT. Assessing ESCROs: yesterday and tomorrow. Am J Bioeth. 2013;13:44-52.

75. Master Z, Resnik DB. Promoting public trust: ESCROs won't fix the problem of stem cell tourism. Am J Bioeth. 2013;13:53-5.

76. Scott CT. Backward by design: building ELSI into a stem cell science curriculum. Hast Cent Rep. 2015;45:26-32.

77. Heitman E. The roots of honor and integrity in science. In: Bulger RE, Heitman E, Reiser SJ, editors. The ethical dimensions of the biological and health sciences. Cambridge: Cambridge University Press; 2002. p. 21-8.

78. Resnik DB. The ethics of science: an introduction. Madison, NY: Routledge; 1998.

79. Office of Research Integrity. PHS policy on instruction in the responsible conduct of research (RCR). 2000.

80. Mastroianni AC, Kahn JP. Encouraging accountability in research: a pilot assessment of training efforts 1 . Accountability in Research. 1999;7:85-100.

81. Steneck NH, Bulger RE. The history, purpose, and future of instruction in the responsible conduct of research. Acad Med. 2007;82:829-34.

82. Master Z. The ethics and governance of research integrity in Canada. Health Law Rev. 2012;20:5-14.

83. Gruen L. The moral status of animals. Stanford Encyclopedia of Philosophy. 2010. http://plato.stanford.edu/entries/moral-animal/. Accessed 15 May 2016. 
84. Singer P. Animal liberation. New York: Random House; 1995.

85. Regan $\mathrm{T}$. The case for animal rights. Berkeley, CA: University of California Press; 1983.

86. Cohen $\mathrm{C}$. The case for the use of animals in biomedical research. N Engl J Med. 1986;315:865-70.

87. Garner JP. The significance of meaning: why do over $90 \%$ of behavioral neuroscience results fail to translate to humans, and what can we do to fix it? ILAR J. 2014;55:438-56.

88. Russell WMS, Burch RL, Hume CW. The principles of humane experimental technique. London: Methuen; 1959.

89. Emanuel EJ, Wendler D, Grady C. What makes clinical research ethical? JAMA. 2000;283:2701-11. This article summarizes the norms and practices for ethical research involving human subjects.

90. McDonald M, Meslin E. Research ethics as social policy: some lessons from experiences in Canada and in the United States. Tocqueville Review. 2003;24:61-85.

91. Brody BA. The ethics of biomedical research: an international perspective. New York: Oxford University Press, USA; 1998.

92. Smith E, Master Z. Ethical practice of research involving humans. Reference Module in Biomedical Research. 2014. doi:10.1016/B978-0-12-801238-3.00178-1.

93. Caulfield T, Rachul C, Zarzeczny A. The evolution of policy issues in stem cell research: an international survey. Stem Cell Rev Rep. 2012;8(4):1037-42.

94. Master Z. Ethics of stem cell research: the unresolved issues. Reference Module in Biomed Res. 2014. doi:10.1016/B978-012-801238-3.00021-0. This review provides a thorough summary of the contemporary ethics issues in stem cell research.

95. Marquis D. An argument that abortion is wrong. In: Arthur J, editor. Morality and moral controversies: readings in moral, social and political philosophy. NJ: Prentice Hall; 2002. p. 218-27.

96. Steinbock B. Respect for human embryos. In: Lauritzen P, editor. Cloning and the future of human embryo research. New York: Oxford University Press; 2001. p. 21-33.

97. Warren MA. On the moral and legal status of abortion. The Monist 1973:43-61.

98. Dickenson D. Ethics watch: the threatened trade in human ova. Nat Rev Genet. 2004;5:167.

99. Baylis F. Animal eggs for stem cell research: a path not worth taking. Am J Bioeth. 2008;8:18-32.

100. Master Z, Resnik DB. Hype and public trust in science. Sci Eng Ethics. 2013;19:321-35.

101. Caulfield T, Sipp D, Murry CE, Daley GQ, Kimmelman J. Scientific community: confronting stem cell hype. Science. 2016;352:776-7.

102. Knowles LP. Stem cell hype and the dangers of stem cell "tourism.”: Ethics White Paper for the Stem Cell Network 2009.

103. Ryan KA, Sanders AN, Wang DD, Levine AD. Tracking the rise of stem cell tourism. Regen Med. 2010;5:27-33.

104. Sipp D. Stem cells and regenerative medicine on the Asian horizon: an economic, industry and social perspective. Regen Med. 2009;4:911-8.

105. Connolly R, O’Brien T, Flaherty G. Stem cell tourism-a webbased analysis of clinical services available to international travellers. Travel Med Infect Dis. 2014;12:695-701.

106. Turner L, Knoepfler P. Selling stem cells in the USA: accessing the direct-to-consumer industry. Cell Stem Cell. 2016;19:154-7.

107. Berger I, Ahmad A, Bansal A, Kapoor T, Sipp D, Rasko JEH. Global distribution of businesses marketing stem cell-based interventions. Cell Stem Cell. 2016;19:158-62.

108. Zarzeczny A, Caulfield T, Ogbogu U, Bell P, Crooks VA, Kamenova K, et al. Professional regulation: a potentially valuable tool in responding to "stem cell tourism. Stem Cell Reports. 2014;3:379-84.
109. Master Z, Sipp D. A role patient advocacy in countering the premature commercialization of stem cell interventions. The Monitor. 2013;27:26-30.

110. Master Z, Robertson K, Frederick D, Rachul C, Caulfield T. Stem cell tourism and public education: the missing elements. Cell Stem Cell. 2014;15:267-70.

111. Master Z, Resnik DB. Stem-cell tourism and scientific responsibility. Stem-cell researchers are in a unique position to curb the problem of stem-cell tourism. EMBO Rep. 2011;12:992-5.

112. Cohen CB, Cohen PJ. International stem cell tourism and the need for effective regulation: part II: developing sound oversight measures and effective patient support. Kennedy Inst Ethics J. 2010;20:207-30.

113. Lindvall O, Hyun I. Medical innovation versus stem cell tourism. Science. 2009;324:1664.

114. International Society for Stem Cell Research. Guidelines for stem cell research and clinical translation. http://www.isscr. org/docs/default-source/guidelines/isscr-guidelines-for-stemcell-research-and-clinical-translation.pdf?sfvrsn=2. Accessed 1 June 2016

115. Rohn J. California's CIRM courts industry. Nat Biotechnol. 2012;30:572.

116. Trounson A, DeWitt ND. Stem cell biology: towards the reality of cell therapeutics. Nat Cell Biol. 2012;14:331.

117. Woolf SH. The meaning of translational research and why it matters. JAMA. 2008;299:211-3.

118. Mowery DC, Nelson RR, Sampat BN, Ziedonis AA. The growth of patenting and licensing by US universities: an assessment of the effects of the Bayh-Dole act of 1980 . Res Policy 2001;30:99-119.

119. Shane S. Encouraging university entrepreneurship? The effect of the Bayh-Dole Act on university patenting in the United States. J Bus Venturing. 2004;19:127-51.

120. Murdoch C, Caulfield T. Commercialization, patenting and genomics: researcher perspectives. Genome Med. 2009;1:22.

121. Bubela TM, Caulfield T. Role and reality: technology transfer at Canadian universities. Trends Biotechnol. 2010;28:447-51.

122. Hong W, Walsh JP. For money or glory? Commercialization, competition, and secrecy in the entrepreneurial university. Sociol Quart. 2009;50:145-71.

123. Caulfield T, Ogbogu U, Murdoch C, Einsiedel E. Patents, commercialization and the Canadian stem cell research community. Regen Med. 2008;3:483-96.

124. Caulfield T, Harmon SH, Joly Y. Open science versus commercialization: a modern research conflict? Genome Med. 2012;4:17.

125. Sismondo S. Ghost management: how much of the medical literature is shaped behind the scenes by the pharmaceutical industry? PLoS Med. 2007;4:e286.

126. Sismondo S. How pharmaceutical industry funding affects trial outcomes: causal structures and responses. Soc Sci Med. 2008;66:1909-14.

127. Critchley CR, Bruce G, Farrugia M. The impact of commercialisation on public perceptions of stem cell research: exploring differences across the use of induced pluripotent cells, human and animal embryos. Stem Cell Rev Rep. 2013;9:541-54.

128. Knoepfler PS. When patients reach out, scientists should reach back carefully. Nat Med. 2016;22:230.

129. Master Z, Caulfield T. Patient booklet: what you need to know about stem cell therapies. http://oirm.ca/sites/default/files/aboutorim/sc_patient_booklet_feb_2014.pdf. Accessed 1 June 2016.

130. International Society for Stem Cell Research. A closer look at stem cells. http://www.closerlookatstemcells.org Accessed 1 June 2016. 
131. Master Z, Campo-Engelstein L, Caulfield T. Scientists' perspectives on consent in the context of biobanking research. Eur J Hum Genet. 2015;23:569-74.

132. Murphy J, Scott J, Kaufman D, Geller G, LeRoy L, Hudson K. Public perspectives on informed consent for biobanking. Am J Public Health. 2009;99:2128-34.

133. Rachul C, McGuire A, Caulfield T. Public perceptions and biobanking: what does the research really say? Stud Ethics Law Technol. 2012;6:Article 3.

134. Wiwchar D. Genetic researcher uses Nuu-Chah-Nulth blood for unapproved studies in genetic anthropology. Ha-Shilth-Sa-A First Nations Newspaper; 2000.
135. Dalton R. Tribe blasts' exploitation of blood samples. Nature. 2002;420:111.

136. Mello MM, Wolf LE. The Havasupai Indian tribe case-lessons for research involving stored biologic samples. N Engl J Med. 2010;363(3):204-7.

137. Doerr A. A newborn bloodspot litigation: 70 days to destroy 5+ million samples. Genomics Law Report 2010; http:/www. genomicslawreport.com/index.php/2010/02/02/newborn-bloodspot-litigation-70-days-to-destroy-5-million-samples/. Accessed 19 August 2016. 